\title{
MENINGKATKAN KEAKTIFAN SISWA KELAS 4 DALAM PROSES PEMBELAJARAN DI MI YANIDA
}

\author{
Widia Kartika ${ }^{1}$, Nadia Nurrohmah ${ }^{2}$, Sarah As-sikah ${ }^{3}$ \\ Universitas Muhammadiyah Tangerang \\ sarahassikah@gmail.com
}

\begin{abstract}
In this study, he will examine student learning outcomes using the demonstration method in his learning on Pkn subjects. This study aims to find out how to use the demonstration method, using the demonstration method for learning outcomes of 4th grade students at MI Yanida. Data collection methods in this study use the method namely: Method of observation, interviews. The results of this study will test student learning outcomes taught by using the demonstration method in MI subjects at Yanida MI, the use of demonstration methods by teachers in grade 4 students for Pkn subjects in accordance with the guidelines for implementing good demonstration methods so that good learning results are obtained. from the use of demonstration methods conducted by the teacher. the use of demonstration methods in describing student learning outcomes by using the demonstration method in pkn for grade 4 students shows good results.
\end{abstract}

Keywords: Methods, Learning, Demonstration

\begin{abstract}
Abstrak : Dalam penelitian ini, ia akan memeriksa hasil belajar siswa menggunakan metode demonstrasi dalam pembelajarannya pada mata pelajaran Pkn. Penelitian ini bertujuan untuk mengetahui bagaimana menggunakan metode demonstrasi, menggunakan metode demonstrasi untuk hasil belajar siswa kelas 4 di MI Yanida. Metode pengumpulan data dalam penelitian ini menggunakan metode yaitu: Metode observasi, wawancara. Hasil penelitian ini akan menguji hasil belajar siswa yang diajarkan dengan menggunakan metode demonstrasi pada mata pelajaran MI di Yanida MI, penggunaan metode demonstrasi oleh guru di kelas 4 siswa untuk mata pelajaran Pkn sesuai dengan pedoman untuk menerapkan metode demonstrasi yang baik sehingga baik hasil belajar diperoleh. dari penggunaan metode demonstrasi yang dilakukan oleh guru. penggunaan metode demonstrasi dalam menggambarkan hasil belajar siswa dengan menggunakan metode demonstrasi di pkn untuk siswa kelas 4 menunjukkan hasil yang baik.
\end{abstract}

Kata Kunci: Metode, Pembelajaran, Demonstrasi

Manazhim : Jurnal Manajemen dan Ilmu Pendidikan

Volume 2, Nomor 1, Februari 2020; 70-80

https://ejournal.stitpn.ac.id/index.php/manazhim 


\section{PENDAHULUAN}

Konsep pembelajaran menurut Corey (Sagala, 2010) adalah "suatu proses dimana lingkungan seseorang secara disengaja dikelola untuk memungkinkan ia turut serta dalam tingkah laku tertentu dalam kondisi-kondisi khusus atau menghasilkan respon terhadap situasi tertentu, pembelajaran merupakan subset khusus dari pendidikan". Lingkungan belajar hendaknya dikelola dengan baik karena pembelajaran memiliki peranan penting dalam pendidikan. Sejalan dengan pendapat Sagala (2010) bahwa pembelajaran adalah "membelajarkan siswa menggunakan asas pendidikan maupun teori belajar merupakan penentu utama keberhasilan pendidikan”. Dalam Peraturan Menteri Pendidikan Nasional Nomor 41 Tahun 2007 mengenai Standar Proses untuk Satuan Pendidikan Dasar dan Menengah, diuraikan bahwa: "pembelajaran adalah proses interaksi peserta didik dengan guru dan sumber belajar pada suatu lingkungan belajar. Proses pembelajaran perlu direncanakan, dilaksanakan, dinilai, dan diawasi. Pelaksanaan pembelajaran merupakan implementasi dari RPP. Pelaksanaan pembelajaran meliputi kegiatan pendahuluan, kegiatan inti dan kegiatan penutup.”. Konsep model pembalajaran menurut Trianto (2010), menyebutkan bahwa model pembelajaran adalah suatu perencanaan atau pola yang digunakan sebagai pedoman dalam merencanakan pembelajaran di kelas atau pembelajaran tutorial. Model pembelajaran mengacu pada pendekatan pembelajaran yang akan digunakan, termasuk di dalamnya tujuan-tujuan pengajaran, tahap-tahap dalam kegiatan pembelajaran, lingkungan pembelajaran, dan pengelolaan kelas.

Pembelajaran mengacu pada pendekatan pembelajaran yang akan digunakan, termasuk di dalamnya tujuan-tujuan pengajaran, tahap-tahap dalam kegiatan pembelajaran, lingkungan pembelajaran, dan pengelolaan kelas. Sedangkan metode pembelajaran menurut Djamarah, SB. (2006: 46) "suatu cara yang dipergunakan untuk mencapai tujuan yang telah ditetapkan'. Dalam kegiatan belajar mengajar, metode diperlukan oleh guru agar penggunaanya bervariasi sesuai yang ingin dicapai setelah pengajaran berakhir.

Dari konsep pembelajaran, model dan metode pembelajaran dapat didefinisikan bahwa model pembelajaran adalah prosedur atau pola sistematis yang digunakan sebagai pedoman untuk mencapai tujuan pembelajaran didalamnya 
terdapat strategi, teknik, metode, bahan, media dan alat penilaian pembelajaran. Sedangkan metode pembelajaran adalah cara atau tahapan yang digunakan dalam interaksi antara peserta didik dan pendidik untuk mencapai tujuan pembelajaran yang telah ditetapkan sesuai dengan materi dan mekanisme metode pembelajaran. Model \& Metode Pembelajaran di Sekolah Sedangkan metode pembelajaran menurut Djamarah, SB. (2006) "suatu cara yang dipergunakan untuk mencapai tujuan yang telah ditetapkan'. Dalam kegiatan belajar mengajar, metode diperlukan oleh guru agar penggunaanya bervariasi sesuai yang ingin dicapai setelah pengajaran berakhir. ${ }^{1}$

\section{Metode Pembelajaran}

Metode merupakan upaya untuk mengimplementasikan rencana yang sudah disusun dalam kegiatan nyata agar tujuan yang telah disusun tercapai secara optimal. Metode digunakan untuk merealisasikan strategi yang telah ditetapkan. Strategi menunjuk pada sebuah perencanaan untuk mencapi sesuatu, sedangkan metode adalah cara yang dapat digunakan untuk melaksanakan strategi.

Adanya penggunaan metode pembelajaran dan prestasi belajar siswa yang baik di sekolah menunjukkan adanya upaya dalam peningkatan kualitas proses pembelajaran di sekolah. Sekolah yang memiliki guru professional akan mampu dalam pengelolaan proses pembelajaran serta mampu menerapkan metode pembelajaran yang akan digunakan dalam proses pembelajaran sehingga akan adanya peningkatan prestasi belajara siswa di sekolah.

Dari hasil penelitian didapati metode pembelajaran berpengaruh terhadap peningkatan prestasi belajar siswa, dalam proses pembelajaran di sekolah guru dapat menggunakan berbagai metode pembelajaran yang tepat dan sesuai dengan kebutuhan siswa di sekolah, guru dapat menggunakan metode ceramah (Preaching Method), metode percobaan (Experimental method), metode latihan keterampilan (Drill method), metode diskusi (Discussion method), metode pemecahan masalah (Problem solving method), metode perancangan (projeck method), metode pembelajaran tersebut memiliki pengaruh yang kuat dan sedang terhadap peningkatan

1 Muhamad Afandi, dkk. Model dan Metode Pembelajaran di Sekolah, (Semarang: Sultan Agung Press, 2013), hlm 15. 
prestasi belajar siswa, setiap metode pembelajaran memiliki peranan dan keunggulan masing-masing, untuk itu diperlukan kemampuan guru dalam menyesuaikan metode pembelajaran dalam proses pembelajaran.

Secara keseluruhan metode pembelajaran akan memberikan berbagai manfaat bagi guru dan siswa di sekolah, guru sangat dituntut untuk mampu dalam menggunakan metode pembelajaran, banyaknya metode pembelajaran yang dikuasai dan dimiliki seorang guru akan mempermudah dan meningkatkan kualitas proses pembelajaran itu sendiri, hal ini didasari pada rumusan metode pembelajaran itu sendiri. Metode pembelajaran mengacu pada tujuan-tujuan pengajaran, tahap-tahap dalam kegiatan pembelajaran, lingkungan pembelajaran dan pengelolaan kelas (Arends, 1997). ${ }^{2}$

\section{METODE}

Metode pengumpulan data merupakan alat penting dalam penelitian yang bertujuan untuk mendapatkan data yang diperlukan. Metode pengumpulan data dalam penelitian ini menggunakan metode yaitu:

1. Metode observasi

Observasi merupakan pengamatan secara sistematis, yaitu pengamatan yang dilakukan dengan menggunakan pedoman observasi sebagai instrument pengamatan yang telah dirancang tentang apa yang diamati dan dimana tempatnya. Observasi dilakukan untuk mengamati secara langsung kegiatan belajar mengajar dengan menggunakan metode demonstrasi untuk mengatahui suasana kegiatan pengajaran terbaik pada proses pembelajaaran.

2. Wawancara

Dalam penelitian ini adalah untuk digunakan sebagai kelengkapan untuk memperoleh data tentang kendala-kendala yang dihadapi selama penggunaan metode demonstrasi. Pengumpulan data yang dilakukan dengan wawancara terhadap pihak yang berkompoten dalam pembelajaran metode demonstrasi, yaitu

2 Mardiah Kalsum Nasution, "Penggunaan Metode Pembelajaran Dalam Peningkatan Hasil Belajar Siswa" Jurnal Ilmiah Bidang Pendidikan Vol. 11 No.1, 2017, Hal 12 \& 14. 
guru dan kepala sekolah. Teknik wawancara dikemukakan secara bebas, artinya kalimat atau pertanyaan tidak terpaku pada pedoman wawancara yang ada, namun pertanyaan dapat diperdalam dan dikembangkan sesuai dengan kondisi lapangan. Dengan demikian jawaban yang diperoleh bias meliputi semua variabel dengan keterangan yang lengkap dan mendalam.

\section{Partisipan}

1. siswa

Dalam penelitian ini siswa dijadikan subyek untuk pengambilan data untuk mengetahui motivasi dan hasil belajar siswa dengan menggunakan metode demonstrasi. Untuk pengambilan data pada siswa, peneliti menggunakan teknik observasi kepada masing-masing untuk siswa kelas 4 di MI Yanida untuk mengetahui hasil belajar siswa dengan menggunakan metode demonstrasi dalam proses pembelajaran.

2. Guru

Guru dijadikan sebagai subyek untuk pengambilan data berupa kesiapan proses pembelajaran, hasil belajar siswa, dan keefektifan proses pembelajaran dengan menggunakan metode demonstrasi, pengambilan data dilakukan dengan wawancara kepada guru pengampu mata pelajaran pkn yang menggunakan metode demonstrasi dalam proses pembelajarannya, dan untuk mengetahui kendala atau hambatan yang terjadi pada saat pembelajaran dengan metode demonstrasi. Partisipan adalah orangorang yang terlibat dalam penelitian yang menjadi sumber data utama atau data pendukung.

\section{Instrumen}

Instrumen Penelitian Instrumen dalam penelitian ini digunakan pedoman observasi dan pertanyaan dalam wawancara. 
Tabel. 1 Kisi-kisi pedoman observasi

\begin{tabular}{|l|l|}
\hline NO & Indikator \\
\hline 1 & Kedisiplinan siswa \\
\hline 2 & Perilaku siswa dikelas \\
\hline 3 & Komunikasi guru dengan siswa dikelas \\
\hline
\end{tabular}

Tabel. 2 Garis-garis besar dari pedoman wawancara

\begin{tabular}{|l|l|}
\hline No & Indikator \\
\hline 1 & Kesiapan Guru dalam proses penggunaan Metode demonstrasi. \\
\hline 2 & Keefektifan selama pembelajaran metode demonstrasi \\
\hline 3 & $\begin{array}{l}\text { Hambatan-hambatan dalam menggunakan metode demonstrasi dan upaya } \\
\text { yang telah dilakukan oleh pihak sekolah }\end{array}$ \\
\hline 4 & $\begin{array}{l}\text { Motivasi belajar terhadap mata pelajaran selama berlangsungnya metode } \\
\text { demonstrasi }\end{array}$ \\
\hline
\end{tabular}

\section{Teknik Pengumpulan Data}

Metode dan teknik pengumpulan data

Metode pengumpulan data merupakan alat penting dalam penelitian yang bertujuan untuk mendapatkan data yang diperlukan. Metode pengumpulan data dalam penelitian ini menggunakan metode yaitu:

1. Metode observasi

Observasi merupakan pengamatan secara sistematis, yaitu pengamatan yang dilakukan dengan menggunakan pedoman observasi sebagai instrument pengamatan yang telah dirancang tentang apa yang diamati dan dimana tempatnya. Observasi dilakukan untuk mengamati secara langsung kegiatan belajar mengajar dengan 
menggunakan metode demonstrasi untuk mengatahui suasana kegiatan pengajaran terbaik pada proses pembelajaaran.

2. Wawancara

Dalam penelitian ini adalah untuk digunakan sebagai kelengkapan untuk memperoleh data tentang kendala-kendala yang dihadapi selama penggunaan metode demonstrasi. Pengumpulan data yang dilakukan dengan wawancara terhadap pihak yang berkompoten dalam pembelajaran metode demonstrasi, yaitu guru dan kepala sekolah. Teknik wawancara dikemukakan secara bebas, artinya kalimat atau pertanyaan tidak terpaku pada pedoman wawancara yang ada, namun pertanyaan dapat diperdalam dan dikembangkan sesuai dengan kondisi lapangan. Dengan demikian jawaban yang diperoleh bias meliputi semua variabel dengan keterangan yang lengkap dan mendalam.

\section{Teknik Analisis Data}

Teknik analisis data yang digunakan dalam penelitian ini adalah analisis diskriptif, artinya data yang diperoleh dalam penelitian ini disajikan apa adanya kemudian di analisis secara diskriptif untuk mendapatkan gambaran mengenai fakta yang ada.

Teknik analisis dalam penelitian ini untuk menganalisis implementasi metode demonstrasi yang dilakukan oleh guru adalah dengan mendiskripsikan penggunaan metode observasi oleh guru. Peneliti menilai tahap - tahap penggunaan metode demonstrasi yang dilakukan oleh guru dengan berpedoman dengan lembar observasi yang telah disusun. Dari data - data yang didapatkan tersebut kemudian ditabulasikan dan dianalisis apakah penggunaan metode demonstrasi oleh guru telah sesuai dengan pedoman operasional metode demonstrasi, sehingga diperoleh jawaban permasalahan yang telah dirumuskan. 


\section{HASIL DAN PEMBAHASAN}

Hasil penelitian ini akan mengkaji hasil belajar siswa yang diajar dengan menggunakan metode demonstrasi pada mata pelajaran pkn di MI Yanida, berikut ini akan di uraikan mengenai penggunaan metode Demonstrasi untuk lebih aktif dalam proses pembelajaran.

1. Hasil penelitian prosedur penggunaan metode Demonstrasi guru

Dalam proses pembelajaran pada mata pelajaran pkn kelas 4 telah melakukan prosedur penggunaan prosedur penggunaan metode demonstrai yaitu:

a. Merumuskan tujuan yang harus dicapai oleh siswa setelah proes demontrasi berakhir

b. Mempersiapkan langkah-langkah demontrasi yang akan dilakukan.

c. Mengatur tempat duduk yang memungkinkan semua siswa dapat memperhatikan dengan jelas apa yang didemontrasikan

d. Mengemukakan tujuan apa yang harus dicapai oleh siswa.

e. Mengemukakan tugas-tugas apa yang harus dilakukan oleh siswa, misalnya siswa ditugaskan untuk mencatat hal-hal yang dianggap penting dari pelaksanaan demonstrasi.

f. Memulai demonstrasi dengan kegiatan-kegiatan yang merangsang siswa untuk berpikir, misalnya melalui pertanyaan-pertanyaan yang mengandung teka-teki sehingga mendorong siswa untuk tertarikmemperhatikan demonstrasi.

g. Menciptakan suasana yang menyejukkan dengan menghindari suasana yang menegangkan.

h. Meyakinkan bahwa semua siswa mengikuti jalannya demonstrasi dengan memperhatikan reaksi seluruh siswa.

i. Memberikan kesempatan kepada siswa untuk secara aktif memikirkan lebih lanjut sesuai dengan apa yang dilihat dari proses demonstrasi itu.

j. Guru memberikan tugas-tugas yang ada kaitannya dengan pelaksanaan demonstrasi dan proses pencapaian tujuan pembelajaran, apabila demonstrasi selesai dilakukan. 
k. Guru dan siswa melakukan evaluasi bersama tentang jalannya proses demonstrasi untuk perbaikan selanjutnya. Bersama siswa mengevaluasi pelaksanaan dan hasil belajar siswa.

\section{PEMBAHASAN}

Belajar merupakan proses perubahan perilaku dimana proses tersebut didahului oleh pengalaman dan hasil perubahan perilaku bersifat lebih permanen. Keberhasilan dari belajar berkaitan dengan penguasaan materi, pengetahuan atau keterampilan yang dikembangkan oleh mata pelajaran dapat dilihat dari hasil belajarnya. Indikator hasil belajar berupa angka - angka yang dituangkan dalam nilai raport, indeks prestasi, dan sebagainya

Dalam penelitian ini akan mengkaji hasil belajar siswa dengan menggunakan metode demonstrasi dalam pembelajaranya pada mata pelajaran tune up motor bensin. Namun dalam pencapaian hasil belajar tersebut juga akan mengetahui seberapa besar motivasi siswa dalam pembelajaran dengan menggunakan metode demonstrasi, Penelitian ini bertujuan untuk mengetahui bagaimana prosedur penggunaan metode demonstrasi, serta bagaimana juga motivasi siswa pada pembelajaran dengan menggunakan metode demonstrasi terhadap hasil belajar siswa kelas 4 di MI Yanida.

Teknik pengumpulan data yang digunakan dalam penelitian ini adalah dengan wawancara, dan dokumentasi. Subyek pada penelitian ini adalah siswa kelas 4 di MI Yanida dan guru kelas. Berdasarkan hasil penelitian tentang metode terbaik dalam mengajak siswa untuk lebih aktif dalam proses pembelajaran bagaimanakah prosedur penggunaan metode demonstrasi pada pelajaran pkn maka diketahui bahwa prosedur penggunaan metode demonstrasi telah sesuai dengan prosedur metode demonstrasi yang benar hal ini dapat diketahui dari observasi telah terlaksananya item - item atau poin yang ada pada metode demonstrasi yang benar, hal ini juga didukung dengan hasil wawancara guru pengampu mata pelajaran yang telah paham dan mengetahui konsep metode demonstrasi yang benar. 
Dari hasil analisis deskriptif untuk motivasi siswa yang diajar menggunakan metode demonstrasi ternyata menunjukkan hasil yang positif dimana,siswa lebih aktif dalam belajar dan berpikir secara kritis hal ini juga didukung oleh hasil wawancara dengan guru yang menyatakan bahwa siswa menyukai metode demonstrasi dan sangat antusias terhadap metode demonstrasi yang digunakan dalam pembelajaran pkn, hasil ini juga didukung dengan hasil wawancara guru dimana guru menyatakan bahwa penyampaian materi dengan metode demonstrasi lebih mudah dan komunikasi yang terjalin antara guru dengan siswa dapat berjalan dengan baik sehingga pemahaman materi oleh siswa dapat meningkat, dan siswa juga sering meningkat pemahaman materinya dengan pembelajaran menggunakan metode demonstrasi.

Berdasarkan uraian diatas maka dapat diambil kesimpulan bahwa pembelajaran dengan metode demonstrasi pada pelajaran pkn di MI Yanida jika dilakukan dengan benar dan sesuai prosedur maka akan menimbulkan motivasi bagi siswa yang secara langsung membuat hasil belajar siswa dapat lebih baik dengan lebih banyak siswa yang mencapai nilai KKM yang telah ditetapkan oleh sekolah.

\section{KESIMPULAN}

Berdasarkan pembahasan, maka kesimpulan dari penelitian ini sebagai berikut:

1. Penggunaan metode demonstrasi oleh guru pada siswa kelas 4 untuk pelajaran pkn sudah sesuai dengan prosedur pedoman pelaksanaan metode demonstrasi yang baik sehingga didapatkan hasil belajar yang baik dari penggunaan metode demonstrasi yang dilakukan oleh guru. Adapun prosedur penggunaan metode demonstrasi secara garis besar sebagai berikut:

a. Persiapan

b. Pelaksanaan

c. Evaluasi

2. Motivasi belajar siswa kelas 4 pada pelajaran pkn sangat positif setelah adanya penggunaan metode demonstrasi.

3. Hasil Belajar siswa dengan menggunakan metode demonstrasi pada pelajaran pkn untuk siswa kelas 4 menunjukkan hasil yang baik. 


\section{DAFTAR PUSAKA}

Anitah, Sri, dkk. 2009. Strategi Pembelajaran. Jakarta: Universitas Terbuka.

Baharudin dan Esa Nur Wahyuni. 2010. Teori Belajar dan Pembelajaran. Jogjakarta: ARRuzz Media.

E. Mulyasa. 2006. Menjadi Guru Profesional: Menciptakan Pembelajaran Kreatif \& Menyenangkan. Bandung.

Kalsum, Mardiah Nasution, 2017. "Penggunaan Metode Pembelajaran Dalam Peningkatan Hasil Belajar Siswa” Jurnal Bidang Pendidikan Vol. 11 No.1, 2017, Hal 12 \& 14.

Muhamad afandi. 2013. Model dan Metode Pembelajaran di Sekolah. Semarang: UNISSULA PRESS

Oemar Hamalik. 2004. Proses Belajar Mengajar. Bandung: Bumi Aksara.

2008. Model Pembelajaran Menciptakan Proses Belajar Mengajar yang Kreatif dan Efektif. Jakarta: Bumi Aksara.

Silverius, S. 1991. Evaluasi Hasil Belajar dan Umpan Balik. Jakarta : Grasindo

Wahab, Aziz. 2008. Metode dan model-model mengajar.Bandung:Alfabeta.

Zain. 2010:86. Langkah-langkah pembelajaran diskusi. 14 januari 17:59. 